九州大学学術情報リポジトリ

Kyushu University Institutional Repository

\title{
Digitalization, Energy Intensity and Economic Growth: A Panel Study on South Asian Economies
}

Hosan, Shahadat

International Institute for Carbon-Neutral Energy Research (WPI-I2CNER) Kyushu University

Shamal Chandra Karmaker

International Institute for Carbon-Neutral Energy Research (WPI-I2CNER) Kyushu University

Md. Matiar Rahman

International Institute for Carbon-Neutral Energy Research (WPI-I2CNER) Kyushu University

Md. Azad Uddin

Graduate School for International Development and Cooperation, Hiroshima University, Hiroshima

他

https://doi.org/10.5109/4738553

出版情報: Proceedings of International Exchange and Innovation Conference on Engineering \& Sciences (IEICES). 7，pp. 19-25，2021-10-21. 九州大学大学院総合理工学府

バージョン:

権利関係 : 


\title{
Digitalization, Energy Intensity and Economic Growth: A Panel Study on South Asian Economies
}

\author{
Shahadat Hosan ${ }^{1,2}$, Shamal Chandra Karmaker ${ }^{1,2,4}$, Md. Matiar Rahman ${ }^{1,4}$, Md. Azad Uddin ${ }^{3}$ and Bidyut Baran Saha ${ }^{1,2 *}$ \\ ${ }^{1}$ International Institute for Carbon-Neutral Energy Research (WPI-I2CNER) Kyushu University, 744 Motooka, Nishi-ku, \\ Fukuoka-shi, Fukuoka 819-0395, Japan \\ ${ }^{2}$ Mechanical Engineering Department, Kyushu University, 744 Motooka, Nishi-ku, Fukuoka-shi, Fukuoka 819-0395, \\ Japan \\ ${ }^{3}$ Graduate School for International Development and Cooperation, Hiroshima University, Hiroshima, Japan. \\ ${ }^{4}$ Department of Statistics, University of Dhaka, Dhaka-1000, Bangladesh \\ ${ }^{*}$ Corresponding author email: saha.baran.bidyut.213@m.kyushu-u.ac.jp
}

\begin{abstract}
This study explores how economic development in South Asian countries could be boosted by recognizing potential of digital innovation, and ensuring energy efficiency in an age of digital economy. The relationship between digitalization, energy intensity, and economic growth in South Asian economies has not been well investigated. As a result, the goal of this research is to use advanced econometric approaches to analyze the relationship between these variables for the period of 1995-2018. The findings imply that digitization boosts economic growth in the countries investigated. Furthermore, energy intensity is inversely related to economic growth. In policy perspective, this study argues that leveraging the benefits of digital innovation in the energy sector will improve long-term economic performance.
\end{abstract}

Keywords: digitalization; energy intensity; sustainable economic growth; energy efficiency.

\section{INTRODUCTION}

Sustainable economic development in the digital economy demands sustained economic growth and energy efficiency [1-3]. Because of the fast rise of digital technology, energy systems around the world are expected to become more integrated, intelligent, reliable, and sustainable [4]. A wide spectrum of energy industries is becoming increasingly reliant on digitalization. In terms of safety, productivity, accessibility, and sustainability, energy systems are already benefiting from digitalization. Energy businesses have augmented their investment in digital technologies significantly in recent years. For instances, global investment in digital electricity infrastructure and software has amplified by more than $20 \%$ each year since 2014 , reaching 47 billion US dollars (USD) in 2016. Also, in 2016, digital investment was about $40 \%$ higher than global gas-fired power generation investment (34 billion USD) and almost equivalent to India's total energy sector investment (55 billion USD). Moreover, the energy intensity of active control devices is expected to halve over the next 25 years, from roughly $2 \mathrm{kWh}$ per square meter per year in 2010 to $1 \mathrm{kWh} / \mathrm{m} 2 /$ year in 2040, owing to digitalization, economies of scale, and continuous product improvements in the energy sector [5].

Ren et al. [6] revealed that digitalization aids in accelerating the reduction in energy consumption intensity as a result of economic growth. Because of the rapid growth of information technology, most countries throughout the world have developed digitalization policies and see them as a key element of boosting overall competitiveness and achieving the Sustainable Development Goals [7,8]. The internet, with the help of technology advancements, can not only upgrade and optimize energy consumption systems, but also improve energy efficiency on a large scale, culminating in the creation of a sustainable energy development platform to improve energy resource allocation $[9,10]$. As a result, one of the main purposes of this article is to figure out how digitalization affects energy intensity and economic growth. The findings can be used by governments to coordinate economic development, allocate and use energy resources, and support long-term economic and social development.

Digitalization not only drives technological innovation and process reengineering to aid a country's industrial and service sectors in driving economic growth, but it also acts as a catalyst for large-scale employment creation via digital platforms [11]. Emerging nations' existing tech-savvy youth and young labor force (i.e., those classified as "low-income" and "lower-middleincome") may play a vital role in assisting the digitalization process and inclusion, leading to the realization of a digital economy, in the future years [1]. As a result, understanding the linkages between digital innovation, energy intensity, and long-term economic growth is important, and it is at the focus of this research. Despite the tremendous untapped potential, there have been few attempts to analyze the economic impact of digitalization and technological advancement in the context of South Asian countries.

Energy is a substantial element in the economic growth of all economies $[12,13]$. The industry was accounted for $38 \%$ of the world final energy consumption and $24 \%$ of overall $\mathrm{CO}_{2}$ emissions in 2014. The importance of digitalization in boosting energy and material use efficiency will only grow in the future, especially in emerging nations, since industrial output is expected to continue to grow. Enhanced process controls in small and medium-sized businesses in the United States, for example, resulted in an estimated energy savings of USD 330 million at a total investment cost of USD 235 million between 1987 and 2015 [5]. At different stages of development, reducing energy intensity has been proved to be a viable alternative for lowering $\mathrm{CO} 2$ emissions [14-16]. As a result, we want to examine the influence of digitalization and changes in energy intensity on economic growth in growing South Asian economies using comprehensive panel analysis. 
Economic development relies heavily on the energy sector [17-20]. Energy consumption tends to rise as countries transition from labor-intensive agriculture to capital- and energy-intensive industry [21]. As the structural transition continues, they will eventually shift into information-intensive services. As a result, as income rises, energy intensity rises at first, then decline [22]. Ezcurra [23] shows that developing nations tend to converge at a greater energy intensity level, whereas developed countries exhibit at least two diverse convergence levels. According to Stern [24], energy efficiency divergence is usually related to economies that are not progressing economically. Wang [18] and Qi et al. [25] reveal that technological innovation, capital formation, and changes in output structure all contribute to sinking energy intensity. From their findings, it is expected that energy intensity, and digitalization are connected with the economic growth of a nation. As a result, the dynamic relationships between digitalization, energy intensity, and economic growth are investigated in this paper. The study's unique feature is that it incorporates digitization and economic sustainability into the energy efficiency research framework, broadening the scope of research in the field of energy and environmental economics.

\section{EMPIRICAL MODEL AND DATA}

\subsection{Econometric model}

We use the following model in Equation (1) to measure the link between the digitalization, energy intensity, and growth, with urbanization, trade openness, and industrialization as control variables :

$$
Y_{i t}=f\left(D G_{i t}, E N I T_{i t}, U P_{i t}, I N D_{i t}, T O P_{i t}\right)
$$

Where $Y_{\text {it }}$ denotes the gross domestic product (GDP), DG is the digitalization index, ENIT is the energy intensity, UP signifies urbanization, TOP is the trade openess, and IND indicates industrialization. Principal component analysis (PCA) is used for calculating digitalization index. All series are converted into their natural logarithm to smooth the data except digitalization (DG) index. This conversion also helps in decreasing autocorrelation and heteroscedasticity concerns and providing more accurate and reliable results . Equation (2) shows the model in its log-linear form:

$$
\begin{aligned}
\ln Y_{i t}= & \alpha_{0}+\beta_{1} \ln D G_{i t}+\beta_{2} \ln E N I T_{i t}+\beta_{3} \ln U P_{i t} \\
& +\beta_{4} \ln I N D_{i t}+\beta_{5} \ln T O P+u_{i t}
\end{aligned}
$$

Where $\mathrm{i}(1 \ldots \ldots, \mathrm{N}), \mathrm{t}(1 \ldots \ldots, \mathrm{T})$ is cross-sections nations and year, respectively. $\alpha_{0}$ denotes the intercept of the model, $\beta_{1}$ and $\beta_{2}$ are the coefficients of the digitalization, and energy intensity, respectively. The coefficients $\beta_{3}, \beta_{4}$ and $\beta_{5}$ indicate urbanization, industrialization, and trade openness respectively. $u_{i t}$ is error terms.

\subsection{Data sources}

Annual panel data for the period of 1995- 2018 were obtained for five south Asian countries including Bangladesh, India, Sri Lanka, Pakistan, Nepal. The variables utilized in this paper comprise per capita GDP as economic growth, the variable digitalization (DG) is measured using PCA score based on individuals using the internet ( $\%$ of the total population) and mobile cellular subscriptions (per 100 people). The energy intensity is used to measure the quantity of energy required per unit of economic output. Eigenvalues of the PCA components for digitalization are presented in Fig. 1.

Eigenvalues of digitalization

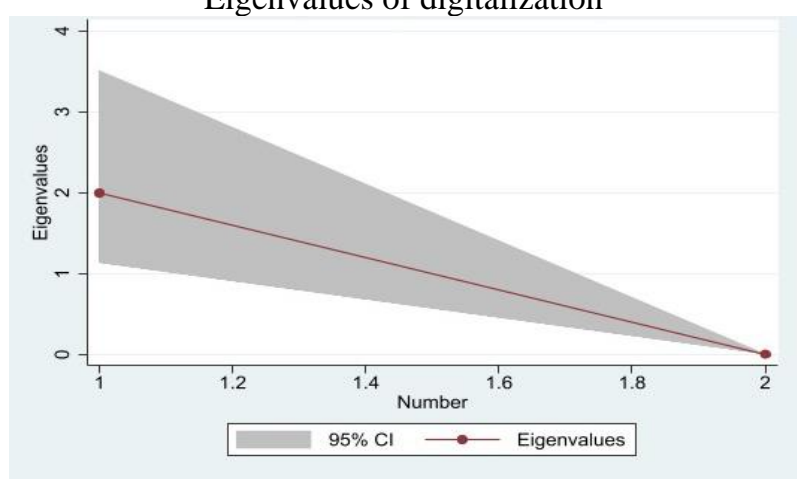

Fig. 1. Plot of eigenvalues of the PCA.

The control variables contain urbanization (UP) measured as urban population (\% of the total population), industrialization (IND), measured as industry value added (\% of GDP) and Trade openness is measured as exports of goods and services measured as share of GDP. The south Asian nations involved in this work were selected subject to the availability of data for all variables. Data comprising $\mathrm{N} * \mathrm{~T}=120$ observations, with $\mathrm{N}=5$ and $\mathrm{T}=24$ are used in this study. All variable data were extracted from the World Development Indicators (WDI) developed by the World Bank [26]. Since the WDI only had data on energy intensity for all nations up to 2015, the data for this variable for the years 2016-2018 came from IEA data sources [27]. Table 1 lists all of the variables and their sources in detail. 
Table 1. Summary of the variables and data.

\begin{tabular}{|c|c|c|c|}
\hline Variables & Sign & Measure & $\begin{array}{c}\text { Data } \\
\text { source }\end{array}$ \\
\hline GDP per capita & $\mathrm{Y}$ & $\begin{array}{c}\text { In constant } 2010 \\
\text { US\$ }\end{array}$ & WDI \\
\hline \multirow[t]{2}{*}{$\begin{array}{c}\text { Digitalization } \\
\text { (PCA Score) }\end{array}$} & DG & $\begin{array}{l}\text { Individual using } \\
\text { internet as \% of } \\
\text { total population }\end{array}$ & WDI \\
\hline & & $\begin{array}{l}\text { Mobile cellular } \\
\text { subscription } \\
\text { as } \% \text { of total } \\
\text { population }\end{array}$ & WDI \\
\hline Energy Intensity & ENIT & $\begin{array}{l}\text { Total primary } \\
\text { energy supply over } \\
\text { GDP measured in } \\
\text { constant } 2011 \text { US\$ }\end{array}$ & WDI \\
\hline Urbanization & UP & $\begin{array}{l}\text { Urbanization } \\
\text { measured as an } \\
\text { urban population } \\
\text { ( } \% \text { of total } \\
\text { population) }\end{array}$ & WDI \\
\hline Industrialization & IND & $\begin{array}{l}\text { Industrialization } \\
\text { measured as } \\
\text { industry value } \\
\text { added as \% of } \\
\text { GDP }\end{array}$ & WDI \\
\hline Trade Openness & TOP & $\begin{array}{l}\text { Exports and } \\
\text { imports of goods } \\
\text { and services } \\
\text { measured as a } \\
\text { share of GDP }\end{array}$ & WDI \\
\hline
\end{tabular}

\subsection{Methodology}

To determine the long-run and dynamic causality among the digitalization, energy intensity, and economic growth, advanced econometric approaches are used in this study. The methodology comprises the steps: 1) a cross-section dependency test 2) second generation panel unit root tests, specifically, CIPS and CADF. 3) panel cointegration tests, including Kao, Pedroni, and Westerlund. 4) estimation of parameters through secondgeneration common correlated effects mean group (CCEMG) method.

\subsubsection{Cross-sectional dependence tests}

The cross-sectional dependency issue in panel data could be caused by the relationship and dependence across countries as a result of globalization and economic collaboration. The study outcomes from such approaches may be biased if the existence of cross-section dependency is not taken into account in the panel $[4,28,29]$. For this reason, we accompanied crosssectional dependence (CD) tests in order to address this issue in the paper. Breusch and Pagan's [30] LM test and Pesaran's [31] CD test are employed for determining the cross-section dependence. Cross-sectional units are assumed to be independent in the null hypothesis, but cross-sectional units are assumed to be dependent in the alternative hypothesis. Breusch and Pagan LM test results are calculated using the equation below:

$$
L M_{B P}=T \sum_{i=1}^{N-1} \sum_{j=i+1}^{N} \hat{r}_{i j}^{2}
$$

The LM test is not effective if the value of T is relatively larger. As an alternate, Pesaran proposes the following $\mathrm{CD}$ test as an approach to solving this problem:

$$
C D_{P}=\sqrt{\frac{2 T}{N(N-1)}}\left(\sum_{i=1}^{N-1} \sum_{j=i+1}^{N} \hat{r}_{i j}^{2}\right)
$$

Where ${ }_{i}$ and $j$ denote the nation, ${ }_{T}$ specifies the year, $\mathrm{N}$ is the number of nations, and $\hat{r}_{i j}^{2}$ indicates the correlation of the error in Eq.(3) and Eq.(4).

\subsubsection{Unit root tests}

To establish the order of data, unit root analysis is used. This method detects if a series is stationary or not (unit root). CIPS and CADF, the second-generation panel unit root tests, are used to solve cross-sectional dependency and produce the most perfect and consistent findings. Pesaran [32] defines cross-section augmented DickeyFuller (CADF) regression as follows:

$$
\Delta X_{i t}=A_{i}+B_{i} X_{i, t-1}+C_{i} \bar{X}_{t-1}+C_{i} \Delta \bar{X}_{t}+e_{i t}
$$

Where $\mathrm{X}$ indicates the target variable, $\Delta$ denotes the difference operator, and $e_{i t}$ is the error term. Pesaran developed the cross-section augmented IPS (CIPS) test using CADF below:

$$
C I P S=\frac{1}{N} \sum_{i=1}^{N} C A D F_{i}
$$

The null hypothesis mentions that each series has a unit root, as opposed to the alternative hypothesis, which states that at least one variable in the panel is stationary.

\subsubsection{Panel cointegration test}

If the unit root tests show that the series is non-stationary, a panel cointegration test is used to figure out the longterm relationship between the variables. In this paper Pedroni [33,34], Kao [35], and Westerlund [36] cointegration approaches are employed. The tests described above are based on residuals calculated from the long-run model, as specified in Eq. 7:

$$
Y_{i t}=\alpha_{i}+\tau_{i} t+\sum_{j=1}^{m} \delta_{j i} X_{j i t}+\varepsilon_{i t}
$$

In Eq. (10), $\mathrm{i}(1,2, \ldots . N) ; j(1,2, \ldots . m)$ and $t(1,2, \ldots . ., T)$ is the cross-section units, number of predictors and number of cases, respectively. $Y$ and $X$ are considered to be integrated of order one. The parameters $\tau_{i}, \alpha_{i}$, and $\delta_{j i}$ denote the trend effect, intercept, and slope coefficient, respectively, and $\varepsilon_{i t}$ is the residual. Eq. (8) can be used to show the estimated residuals:

$$
\varepsilon_{i t}=\rho_{i} \varepsilon_{i t-1}+u_{i t}
$$

$H_{o}: \rho_{i}=1$ is the null hypothesis in the above test, implying no cointegration, as opposed to the alternative $\left(\mathrm{H}_{1}: \rho_{\mathrm{i}}<1\right)$, which specifies the cointegration of all panels.

\subsubsection{Estimation of coefficients}


The long-run parameters are to be estimated after confirming that the variables are cointegrated. The longrun parameters can be measured using common correlated effects mean group (CCEMG) [37] and the augmented mean group (AMG) [38,39]. The CCEMG estimator is resistant to structural breaks and unobserved non-stationary common components. Hence, the CCEMG approach is employed in this study to access the robustness of the examined relationships. The CCEMG uses the following estimating method:

$$
Y_{i t}=\alpha_{i}+\beta_{i} X_{i t}+\delta_{i} \bar{Y}_{i t}+\tau_{i} \bar{X}_{i t}+\varphi_{i} f_{t}+\varepsilon_{i t}
$$

Where ${ }_{\boldsymbol{Y}_{i t}}$ is the dependent variable, $X_{i t}$ is the independent variable, $\beta_{i}$ indicates the slope on the exogenous factor, $\alpha_{i}$ denotes the group fixed effects, $f_{t}$ is the unobserved common factor, and $\varepsilon_{i t}$ is the residual. The CCEMG estimator is developed considering the average of each coefficient across every individual regression, as illustrated below:

$$
C C E M G=\frac{1}{N} \sum_{i=1}^{N} \hat{\beta}_{i}
$$

Where $\hat{\beta}_{i}$ is the estimated value of $\beta_{i}$ in Eq.(10).

\section{RESULTS AND DISCUSSION}

All findings based on indicated methodological approaches are reported in this section. Table 2 displays the results of the cross-section dependence test.

Table 2. Cross-section dependency results.

\begin{tabular}{lcccc}
\hline \multirow{2}{*}{ Variables } & \multicolumn{2}{c}{ LM test } & \multicolumn{2}{c}{ CD test } \\
\cline { 2 - 5 } & Test Stat. & p-value & $\begin{array}{l}\text { Test } \\
\text { Stat. }\end{array}$ & p-value \\
\hline InY & 7952.624 & 0.000 & 87.632 & 0.000 \\
DG & 8635.421 & 0.000 & 89.458 & 0.000 \\
InENIT & 8547.215 & 0.000 & 39.215 & 0.000 \\
InUP & 7351.954 & 0.000 & 53.321 & 0.000 \\
InIND & 2315.710 & 0.000 & 17.527 & 0.000 \\
TOP & 7587.536 & 0.000 & 84.521 & 0.000 \\
\hline
\end{tabular}

The null hypothesis of cross-sectional independence can be rejected for digitalization, energy intensity, economic growth, urbanization, trade openness and industrialization considering the corresponding $\mathrm{p}$-values of LM and CD test statistics of table 2. As a result, crosssection dependence exists for all variables in our study. Before analyzing cointegration, it is necessary to determine whether or not the data are non-stationary. The CIPS and CADF tests were utilized in this work to detect unit roots in the variables under investigation. Table 3 summarizes the findings of these two tests.
Table 3. Results of panel unit root test.

\begin{tabular}{lllll}
\hline \multirow{2}{*}{ Variables } & \multicolumn{3}{c}{ CIPS } & \multicolumn{3}{c}{ CADF } \\
\cline { 2 - 5 } & Level & 1st diff. & Level & 1st diff. \\
\hline InY & -1.758 & $-2.325^{* *}$ & -1.521 & $-2.521^{* *}$ \\
DG & $-2.521^{* *}$ & $-3.321^{* *}$ & -1.452 & $-4.214^{* *}$ \\
InENIT & $-2.214^{*}$ & $-2.421^{* *}$ & -1.451 & $-4.845^{* * *}$ \\
InUP & -1.450 & $-2.951^{* *}$ & -2.231 & $-3.102^{* * *}$ \\
InIND & $-2.105^{*}$ & $-2.521^{* * *}$ & -2.408 & $-3.512^{* * *}$ \\
InTOP & $-1.214^{*}$ & $-2.537^{* *}$ & -1.512 & $-3.521^{* *}$ \\
\hline \multicolumn{5}{r}{ Significant at $\left(^{*} 10 \%{ }^{* *} 5 \%,^{* * *} 1 \%\right)$ level. }
\end{tabular}

According to the hypothesis, the variables are nonstationary, as shown by the results in Table 3. The hypothesis is not rejected at the level in both cases, but the first difference demonstrates significance at the $1 \%$ level. As a result, all of the variables have a unit root at the level, according to the CIPS and CADF tests; however, none of the variables have a unit root at the first difference, which is of degree one I (1). Lastly, all series in Eq. (2) is unit-root having a process of I (1).

The panel cointegration approach was used to find the long-run links among the variables in Eq. (5) since all studied variables were in I (1) process. Table 4 displays the results of three different panel cointegration methods - Pedroni [33,34], Kao [35], and Westerlund [36].

Table 4. Results of panel cointegration tests.

\begin{tabular}{ll}
\hline Approaches & t-value \\
\hline Pedroni & \multicolumn{1}{c}{$6.5621^{* * *}$} \\
Modified Phill-Perron t & $-2.6394^{* * *}$ \\
Phill-Perron t & $-5.4271^{* *}$ \\
Aug. D-Fuller t & \\
Kao & $1.3984^{*}$ \\
Modified D-Fuller t & 0.0621 \\
D-Fuller t & $-2.2154^{* * *}$ \\
Aug. D-Fuller t & $1.2154^{* *}$ \\
Unadj. modified D-Fuller t & 0.2154 \\
Unadj. D-Fuller t & $1.2146^{* * *}$ \\
Westerlund & Variance ratio \\
\hline \multicolumn{2}{c}{ Significance level $\left({ }^{*} 10 \%{ }^{* *} 5 \%,{ }^{* * *} 1 \%\right)}$.
\end{tabular}

In these tests, the null hypothesis is that the panel has no cointegration. Table 4 demonstrates that the variables studied have a long-run relationship, rejecting the null hypothesis at a $1 \%$ significance level. This finding explains why all of the variables in the study are cointegrated.

CCEMG method is used to calculate the long-run coefficients of the estimation, and the CCEMG findings are shown in Table 5. The findings imply that digitization boosts economic growth in the countries investigated. However, energy intensity is inversely related to economic growth, implying that lowering energy intensity enhances economic performance. Our results support the findings of previous studies [1,6]. Energy intensity is adversely connected to the economic growth pattern of nations, and this finding is consistent with the 
result of Deichmann et al. [22], indicating that lowering energy intensity stimulates economic progress in South Asian economies. Findings also reveal that urbanization, trade openness, and industrialization enhance the economic growth for South Asian countries. This finding backs with the results of previous studies [21,40,41].

Table 5. CCEMG estimation results.

\begin{tabular}{lccc}
\hline Variables & coefficients & $\begin{array}{c}\text { Std. error of } \\
\text { coefficient }\end{array}$ & p-value \\
\hline DG & $0.0505^{* * *}$ & 0.0156 & 0.001 \\
lnENIT & $-0.0684^{*}$ & 0.0393 & 0.082 \\
lnUP & 1.0745 & 1.8481 & 0.561 \\
InIND & 0.0778 & 0.0585 & 0.183 \\
InTOP & 0.0438 & 0.0421 & 0.297 \\
\hline
\end{tabular}

Significant at ${ }^{*} 10 \%{ }^{* *} 5 \%,{ }^{* * *} 1 \%$ level.

In summary, the CCEMG findings identify the positive impact of digitalization on economic growth, whereas energy intensity is negatively connected with economic growth. Therefore, government should advocate the strategic policy to encourage digitalization in the energy sector in order to ensure energy efficiency through lowering the energy intensity. The run-run causality among the variables is presented in Fig. 2.

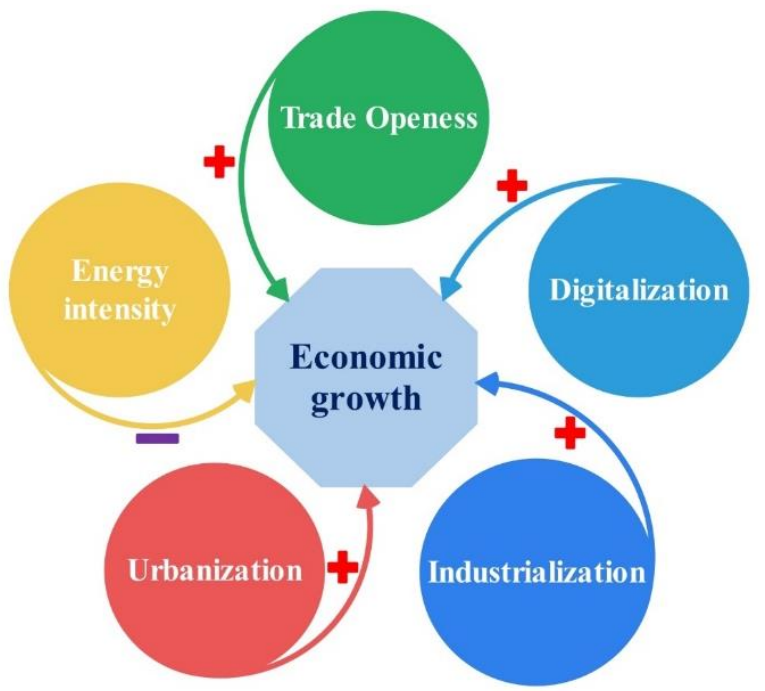

Fig. 2. The graphical long-run causality among studied variables.

\section{CONCLUSIONS AND POLICY IMPLICATIONS}

South Asian countries are well-known for their current rapid growth and digitalization; nevertheless, without policy intervention, their current economic path may prove unsustainable. As a result, existing policies in these nations will need to be altered to better deal with the challenges of reaching SDG targets. By addressing policy concerns related to digitalization growth, this study contributes to the achievement of this goal. The findings show that digitalization and energy intensity have an impact on economic growth. The findings could be applied to enhance a roadmap for developing countries to use digital innovation and energy efficiency in productive sectors to accomplish sustainable development goals.
Technological improvements and reducing prices are driving the digital transformation of energy systems, but policy and market design are crucial in directing the digital transition toward a secure and sustainable path [4,5]. Digitalization is not only a powerful tool for achieving a wide range of policy objectives, but it can also help to speed up the policymaking process. Many aspects of the energy system could benefit from digitalization, but only if policymakers commit to understanding, channeling, and exploiting digitalization's impacts and challenges. For example, digitalization can have an impact on energy consumption by boosting economic development, human capital, R\&D investment, financial development, and industrial structure, all of which can increase the magnitude of energy consumption while lowering its intensity $[6,42,43]$. As a result, it is important to promote the use of digitalization in the energy sector, as well as its deep integration with energy production, intensity, and consumption.

Our findings contribute to the literature from the standpoint of policymaking by highlighting the implementation paths for reaching SDG goals and how digitalization and energy efficiency can act as a catalyst in this process. Despite our investigation's key findings, there are some limitations that need to be investigated further in future research. Data availability is required for robust policy design. Several researchers have identified data availability as a major issue in the context of South Asian economies. We were unable to include additional digitalization indicators in this analysis due to this limitation. Future research should look into the underlying influence of energy consumption on longterm economic growth in the context of a digital economy, focusing on more countries and economies over a longer period of time as data becomes more available.

\section{REFERENCES}

[1] K.A.U. Zaman, T. Sarker, Demographic Dividend, Digital Innovation, and Economic growth: Bangladesh experience, 2021. https://doi.org/10.1007/978-1-349-67278-3_116.

[2] P.K. Adom, M. Agradi, A. Vezzulli, Energy efficiency-economic growth nexus: What is the role of income inequality?, J. Clean. Prod. 310 (2021) 127382. https://doi.org/10.1016/j.jclepro.2021.127382.

[3] Shamal Chandra Karmaker, Md. Matiar Rahman, S. Hosan, Bidyut Baran Saha, The Impact of Biomass Energy Consumption on Human Development: Evidence from Asian Countries, Proc. Int. Exch. Innov. Conf. Eng. Sci. 6 (2020) 204-211. https://doi.org/10.5109/4102489.

[4] S. Chandra Karmaker, S. Hosan, A.J. Chapman, B.B. Saha, The role of environmental taxes on technological innovation, Energy. 232 (2021) 121052. https://doi.org/10.1016/j.energy.2021.121052.

[5] I.E.A.( IEA), Digitalization \& Energy, (2017). 
[6] S. Ren, Y. Hao, L. Xu, H. Wu, N. Ba, Digitalization and energy: How does internet development affect China's energy consumption?, 98

https://doi.org/10.1016/j.eneco.2021.105220.

[7] G. Del Río Castro, M.C. González Fernández, Á. Uruburu Colsa, Unleashing the convergence amid digitalization and sustainability towards pursuing the Sustainable Development Goals (SDGs): A holistic review, J. Clean. Prod. 280 (2021). https://doi.org/10.1016/j.jclepro.2020.122204.

[8] Y. Li, Internet Development and Structural Transformation: Evidence from China, J. Appl. Financ. Bank. 10 (2020) 153-172.

[9] Y. Zuo, F. Tao, A.Y.C. Nee, An Internet of things and cloud-based approach for energy consumption evaluation and analysis for a product, Int. J. Comput. Integr. Manuf. 31 (2018) 337-348. https://doi.org/10.1080/0951192X.2017.1285429.

[10] A. Chapman, Y. Shigetomi, S. Chandra Karmaker, B. Baran Saha, K. Huff, C. Brooks, J. Stubbins, The cultural dynamics of energy: The impact of lived experience, preference and demographics on future energy policy in the United States, Energy Res. Soc. Sci. $80 \quad$ (2021) 102231. https://doi.org/10.1016/j.erss.2021.102231.

[11] B. Rumana, H. Richard, Defining, Conceptualising and Measuring the Digital Economy, 2017. http://www.digitalechancen.de/transfer/downloads/MD280.pdf.

[12] A. Díaz, G.A. Marrero, L.A. Puch, J. Rodríguez, Economic growth, energy intensity and the energy mix, Energy Econ. 81 (2019) 1056-1077. https://doi.org/10.1016/j.eneco.2019.05.022.

[13] I. Khan, F. Hou, A. Zakari, V.K. Tawiah, The dynamic links among energy transitions, energy consumption, and sustainable economic growth: A novel framework for IEA countries, Energy. $222 \quad$ (2021) 119935. https://doi.org/10.1016/j.energy.2021.119935.

[14] J.B. Ang, CO2 emissions, energy consumption, and output in France, Energy Policy. 35 (2007) 4772-4778.

https://doi.org/10.1016/j.enpol.2007.03.032.

[15] G.A. Marrero, Greenhouse gases emissions, growth and the energy mix in Europe, Energy Econ. $\quad 32 \quad$ (2010) 1356-1363. https://doi.org/10.1016/j.eneco.2010.09.007.

[16] N. Apergis, J.E. Payne, K. Menyah, Y. WoldeRufael, On the causal dynamics between emissions, nuclear energy, renewable energy, and economic growth, Ecol. Econ. 69 (2010) 22552260.

https://doi.org/10.1016/j.ecolecon.2010.06.014.

[17] Y. Liu, B. Lin, B. Xu, Modeling the impact of energy abundance on economic growth and $\mathrm{CO} 2$ emissions by quantile regression: Evidence from China, Energy. $227 \quad$ (2021) 120416. https://doi.org/10.1016/j.energy.2021.120416.

[18] C. Wang, Changing energy intensity of economies in the world and its decomposition, Energy Econ. 40 (2013) 637-644. https://doi.org/10.1016/j.eneco.2013.08.014.

[19] S. Hosan, Md. Matiar Rahman, Shamal Chandra Karmaker, Bidyut Baran Saha, The Effect of
Technological Innovation on Environmental Quality: Accounting Ecological Footprint Indicators for Asian Countries, Proc. Int. Exch. Innov. Conf. Eng. Sci. 6 (2020) 198-203. https://doi.org/10.5109/4102488.

[20] S.C. Karmaker, S. Hosan, B.B. Saha, Does biomass energy consumption improve human development? Evidence from South Asian countries, Int. Energy J. 21 (2021) 81-92.

[21] M.M. Rahman, S. Hosan, S.C. Karmaker, A.J. Chapman, B.B. Saha, The effect of remittance on energy consumption: Panel cointegration and dynamic causality analysis for South Asian countries, Energy. $220 \quad$ (2021) 119684. https://doi.org/10.1016/j.energy.2020.119684.

[22] U. Deichmann, A. Reuter, S. Vollmer, F. Zhang, The relationship between energy intensity and economic growth: New evidence from a multicountry multi-sectorial dataset, World Dev. 124 (2019) 104664 https://doi.org/10.1016/j.worlddev.2019.104664.

[23] R. Ezcurra, Distribution dynamics of energy intensities: A cross-country analysis, Energy Policy. $35 \quad$ (2007) 5254-5259. https://doi.org/10.1016/j.enpol.2007.05.006.

[24] D.I. Stern, Modeling international trends in energy efficiency, Energy Econ. 34 (2012) 2200-2208. https://doi.org/10.1016/j.eneco.2012.03.009.

[25] S.Z. Qi, H.R. Peng, Y.J. Zhang, Energy intensity convergence in Belt and Road Initiative (BRI) countries: What role does China-BRI trade play?, J. Clean. Prod. 239 (2019) 118022. https://doi.org/10.1016/j.jclepro.2019.118022.

[26] B. World, Data Bank: World Development Indicators, (2021). https://data.worldbank.org/indicator (accessed April 15, 2021).

[27] IEA, SDG7: Data and Projections, Int. Energy Agency. (2021). https://www.iea.org/reports/sdg7-data-andprojections (accessed March 10, 2021).

[28] M. Aydin, The effect of biomass energy consumption on economic growth in BRICS countries: A country-specific panel data analysis, Renew. Energy. 138 (2019) 620-627. https://doi.org/10.1016/j.renene.2019.02.001.

[29] Z. Wang, Q. Bui, B. Zhang, The relationship between biomass energy consumption and human development: Empirical evidence from BRICS countries, Energy. $194 \quad$ (2020) 116906. https://doi.org/10.1016/j.energy.2020.116906.

[30] T.S. Breusch, A.R. Pagan, The Lagrange Multiplier Test and its Applications to Model Specification in Econometrics, Rev. Econ. Stud. 47 (1980) 239. https://doi.org/10.2307/2297111.

[31] M.H. Pesaran, General Diagnostic Tests for Cross Section Dependence in Panels, Univ. Cambridge USC. 3 (2004) Working Paper No.0435, June 2004.

[32] M.H. Pesaran, A simple panel unit root test in the presence of cross-section dependence, J. Appl. Econom. 22 (2007) 265-312. https://doi.org/10.1002/jae.951.

[33] P. Pedroni, Panel cointegration: Asymptotic and finite sample properties of pooled time series tests 
with an application to the PPP hypothesis, Econom. Theory. 20 (2004) 597-625. https://doi.org/10.1017/S0266466604203073.

[34] P. Pedroni, Critical Values for Cointegration Tests in Heterogeneous Panels with Multiple Regressors, Oxf. Bull. Econ. Stat. 61 (1999) 653-670. https://doi.org/10.1111/1468-0084.61.s1.14.

[35] C. Kao, Spurious regression and residual-based tests for cointegration in panel data, J. Econom. 90 (1999) 1-44. https://doi.org/10.1016/S03044076(98)00023-2.

[36] J. Westerlund, New simple tests for panel cointegration, Econom. Rev. 24 (2005) 297-316. https://doi.org/10.1080/07474930500243019.

[37] M.H. Pesaran, Estimation and inference in large heterogeneous panels with a multifactor error structure, Econometrica. 74 (2006) 967-1012. https://doi.org/10.1111/j.14680262.2006.00692.x.

[38] M. Eberhardt, S. Bond, Cross-section dependence in nonstationary panel models: a novel estimator, Munich Pers. RePEc Arch. (2009).

[39] M. Eberhardt, F. Teal, Productivity Analysis in Global Manufacturing Production., 2010.

[40] L. Charfeddine, The impact of energy consumption and economic development on Ecological Footprint and $\mathrm{CO} 2$ emissions: Evidence from a Markov Switching Equilibrium Correction Model, Energy Econ. 65 (2017) 355374. https://doi.org/10.1016/j.eneco.2017.05.009.

[41] U. Al-Mulali, I. Ozturk, The effect of energy consumption, urbanization, trade openness, industrial output, and the political stability on the environmental degradation in the MENA (Middle East and North African) region, Energy. 84 (2015) 382-389. https://doi.org/10.1016/j.energy.2015.03.004.

[42] X. Shen, B. Lin, Policy incentives, R\&D investment, and the energy intensity of China's manufacturing sector, J. Clean. Prod. 255 (2020) 120208. https://doi.org/10.1016/j.jclepro.2020.120208.

[43] Y. Liu, Y. Zhang, S. Ren, M. Yang, Y. Wang, D. Huisingh, How can smart technologies contribute to sustainable product lifecycle management?, J. Clean. Prod. $249 \quad$ (2020) 119423. https://doi.org/10.1016/j.jclepro.2019.119423. 